\title{
Lighed med hensyn til hvad? Komparativ klimapolitik og politisk teori om lighed ${ }^{1}$
}

Peter Nedergaard

Professor, Institut for Statskundskab, Københavns Universitet

Hovedaktørerne i international klimapolitik - EU, Kina og USA - har forskellige og ikke altid konsistente normer om lighed med hensyn til, hvordan begrænsningerne i udledningerne skal foregå. Det påvises i denne artikel, og det er sandsynligvis medvirkende til, at disse aktører har så svært ved at nå frem til en fælles forståelse endsige en aftale om begrænsninger i udledningerne af drivhusgasser på internationalt plan.

\section{Indledning}

Hvilke politisk-teoretiske normer om lighed ligger til grund for EU, Kina og USA's argumenter for fordelingen af udledningsreduktioner i international klimapolitik? Denne artikel vil søge at besvare dette spørgsmål. Klimapolitikken ser måske ikke ud til at være lige så presserende i international politik som tidligere, fordi noget tyder på, at klimaforandringerne muligvis ikke kommer så hurtigt, som mange troede for få år siden (Polo, Dong og Sutton 2013; Financial Times 2013). Alligevel er klimapolitikken ikke forsvundet fra den internationale scene. Det skyldes, at den grundlæggende årsag til klimaforandringerne stadig findes, hvorfor den internationale politiske aktivitet desangående (f.eks. klimatopmøder) er uforandret (Commission 2013).

De internationale klimaforhandlinger arbejder nu frem mod det 21. klimatopmøde - COP21 i Paris i 2015. Her er målsætningen, at verdens lande skal nå til enighed om en samlet international klimaaftale med udledningsreduktioner for alle lande. Byrdefordelingen af disse reduktioner vil blive et helt afgørende spørgsmål i en kommende klimaaftale. I klimaforhandlingerne repræsenteres byrdefordelingsdiskussionen ved det i FN's klimakonvention forankrede princip om falles, men differentieret ansvar for at bekæmpe klimaforandringer. Hovedaktørerne i klimadebatten anvender imidlertid forskellige politisk-teoriske normer om lighed for fordelingen af udledningsreduktionerne. Nærværende artikel analyserer disse politisk teoretiske synspunkter i klimadebatten, hvilket giver en dybere forståelse af, hvorfor de forskellige aktører indtager de positioner i international klimapolitik, som de gør.

Artiklen er opbygget som følger: Først opstilles de politisk teoretiske argumenter vedrørende byrdefordeling af udledningsreduktioner. Dernæst præsenteres artiklens metode. Herefter kommer analysen af de tre klimapolitiske aktører - Kina, EU og USA, - med hensyn deres til normative position i forhold til de klimapolitiske lighedsprincipper for udledningen af drivhusgasser. Endelig konkluderes der.

\section{Politisk teori}

Politisk teori vedrører bl.a. normative begrundelser af politiske problemstillinger. De har løbende vist sig på det klimapolitiske område. Siden indgåelsen af FN's rammekonvention om klimaforandringer (UNFCCC) ${ }^{2}$ i 1992 er der fremkommet en voksende normativ politisk teoretisk litteratur angående spørgsmålet om fordelingen af retten til at udlede drivhusgasser (Ringius et al. 2002). Baseret på Raymond (2008) er det muligt at samle denne tænkning $\mathrm{i}$ tre indbyrdes forbundne argumenter, beroende på forskellige grundlæggende politisk teoretiske positioner vedrørende lighed (Raymond 2008: 5-8). Disse „bundter“ 
af argumenter hviler hver især på forskellige lighedsprincipper. I denne artikel benævnes de som „skoler“. Denne måde at opdele argumenterne på gør, at de enkelte skoler kommer til at hvile på et fundament af politisk teori, hvilket ikke er tilfældet i f.eks. Ringius et al. (2002).

Dybest set besvarer skolerne på forskellig vis spørgsmålet om „lighed med hensyn til hvad“. Der findes naturligvis andre argumenter i den klimapolitiske debat, men de tre skoler præsenteret i denne artikel kan anses for at være de vigtigste og er bredt dækkende. I det efterfølgende opridses de forskellige lighedsprincipper, der retfærdiggør en given fordeling af udledningen af drivhusgasser og argumenterne, der ligger til grund for dem.

\section{Første skole: Lighed med hensyn til udledning $i$ basisair („Equal Burdens")}

Princippet om lighed med hensyn til udledning i basisår består i virkeligheden af to undergrupper af normer med hensyn til tildelingen af rettigheder. Det ene princip drejer sig om en Hume-baseret norm om, at man har ejendomsret til et gode, når man har besiddet det længe nok (Hume 2004 [1739]: 356). ${ }^{3}$ Det andet princip drejer sig om en mere traditionel Locke-baseret norm om, at man har ret til et gode i kraft af forudgående brug (Locke 1980 [1690]: 18). ${ }^{4}$ Begge normer kan anvendes til at retfærdiggøre fordelingen af udledningsrettigheder baseret på den forståelse, at stater kan betragte retten til at udlede CO2 som et gode. Argumentet er i den forbindelse, at lande som udgangspunkt har ret til udledninger af drivhusgaser på deres nuværende niveau. Hvis dette ikke længere kan lade sig gøre, har de i det mindste ret til, at reduktioner af udledningerne tager udgangspunkt i et givent historisk udledningsniveau, hvilket i de internationale klimapolitiske forhandlinger har været basisåret 1990 .

En Locke-baseret allokering af udledninger af drivhusgasser på baggrund af forudgående brug af et gode kan opfattes som et spørgsmål om naturlige rettigheder. Der er tale om et forhold, der blot politisk anerkendes med henblik på at allokere formelle rettigheder til en eller anden form for naturressource. Følgende diskurs i international klimapolitik kan således ses som hvilende på en Locke-baseret norm: De udviklede lande har ganske vist historisk set udledt langt flest drivhusgasser. Udledningen heraf har imidlertid været forudsætningen for at nå den nuværende grad af industriel og teknologisk udvikling, som også udviklingslandene i dag i høj grad nyder godt af. Dette argument, som ses i litteraturen om teknologihistorie, er hidtil blevet overset i den klimapolitiske litteratur (Nielsen et al. 2005). Ud fra denne normative position er en ligelig byrdefordeling af udledningsreduktionerne med udgangspunkt $\mathrm{i}$ et givent historisk basisår forståelig.
Mere almindelig i international klimapolitik er imidlertid den Hume-baserede norm om, at allokering af udledningsrettigheder bør tage udgangspunkt i en forudgånde besiddelse ("possession“) af et gode snarere end forudgående anvendelse som hos Locke. Denne norm kan identificeres med David Humes syn på ejerskab som en generel Pareto-forbedrende institution for samfundet:

\section{„No one can doubt, that the convention for the distinction of property, and for the stability of possession, is of all circumstances the most necessary to the establishment of human society, and that after the agreement for the fixing and observing of this rule, there remains little or nothing to be done towards settling a perfect harmony and concord“ (Hume 2004 [1739]: 359).}

For Hume indebærer et samfund indrettet med ejendomsret, at alle vinder. Man skal ikke længere ud i en daglig kamp om den private ejendomsret til goderne for at fastslå, hvem der kan anvende samfundets forskelligartede ressourcer. Måden, hvorpå dette kan ske, går imidlertid via en accept af den enkeltes allerede eksisterende besiddelser på de forskellige områder.

Adskillige lande fremsatte Hume-baserede argumenter angående allokeringen af drivhusgasserne i forhandlingerne, som ledte frem til Kyotoprotokollen, hvilket resulterede $\mathrm{i}$, at hele grundlaget for reduktionerne blev baseret på de historiske tal opnået i 1990 (Oberthür og Ott 1999). ${ }^{5}$

\section{Anden skole: Lighed med hensyn til effektivitet („Equal Efficiency")}

Den anden gruppe argumenter angående lighed vedrørende udledningen af drivhusgasser drejer sig om, at eventuelle begrænsninger i udledningerne ikke bør tage udgangspunkt i de totale udledninger af drivhusgasser (som i første skole), men i de relative udledningsrater. Både forskere, kommentatorer og toppolitikere har f.eks. nævnt begrænsninger af drivhusgasudledninger i forhold til bestemte økonomiske indekser som en mulighed. Der vil ofte i praksis være tale om udledninger af drivhusgasser i forhold til en produceret enhed af bruttonationalprodukt eller i forhold til per produceret energienhed (Raymond 2008: 6-7).

Argumenter inden for denne skole anfører bl.a., at mens USA er en af de store udledere af $\mathrm{CO} 2$ per indbygger, er de amerikanske udledninger per enhed BNP faktisk temmelig lave i et internationalt perspektiv og lavere end for visse udviklingslandes vedkommende. Mere generelt forudsætter denne type af argumenter et givent benchmark (Ringius et al. 2002). 
En benchmark-baseret allokering kan f.eks. indebære en tildeling til et land af en bestemt mængde tilladelser til udledning af drivhusgasser per enhed BNP uanset, hvilket niveau landets udledninger historisk havde befundet sig på. En sådan indfaldsvinkel vil belønne lande med flest „rene“ energikilder, som har lave udledninger af drivhusgasser, mens den straffer lande med „beskidte“ energikilder, der indebærer store udledninger af drivhusgasser. Man giver med andre ord herigennem et incitament til, at lande skifter til renere energikilder.

Grundlaget for den anden skole er, at reduktionskravene bør være baseret på en norm om, hvor man får „mest mulig økonomisk vækst for de udledte drivhusgasser". Denne argumentation ses af tilhængerne som udtryk for en moderne, markedsorienteret og incitamentsbaseret allokering af udledningsrettighederne i modsætning til den rent juridisk-administrative allokering, som ligger implicit til grund for den første skole. Cost-benefit kalkuler skal i overensstemmelse med den anden skole være styrende for reguleringen af udledningerne i international klimapolitik.

Argumenter i denne stil var meget almindelige i nogle landes positionspapirer op til forhandlingerne om Kyotoprotokollen. USA var f.eks. allerede dengang fortaler for denne skole. I forbindelse med Kyotoprotokollen blev der på amerikansk initiativ bl.a. etableret såkaldt markedsbaserede ordninger vedrørende handel med udledningsrettigheder med henblik på at effektivisere den internationale klimapolitiske regulering. Det bedste eksempel herpå er Clean Development Mechanism-systemet (CDM), som er baseret på, at anneks I landene ${ }^{6}$ kan købe rettigheder til ekstra udledninger i ikke-anneks I landene $^{7}$ mod til gengæld at finansiere implementeringen af ny og renere teknologi, der reducerer $\mathrm{CO} 2$ - udledningerne tilsvarende. CDM-systemet hviler således klart på det normative grundlag, at udslippene skal begrænses i de lande, hvor det kan gøres billigst, og hvor - med en i den forbindelse ofte brugt metafor - de lavest hængende udledningsfrugter befinder sig (Nedergaard 2011).

\section{Tredje skole: Lighed med hensyn til rettigheder („Equal Rights")}

En tredje skole af klimapolitiske argumenter bygger på princippet om lighed med hensyn til rettigheder („Equal Rights") for mennesker. Ifølge dette perspektiv er enhver borger i verden berettiget til samme andel af atmosfxrens evne til at absorbere drivhusgasser. Det indebærer, at de enkelte lande i verden efter en kortere eller længere overgangsperiode i princippet ville skulle udlede samme mængde drivhusgasser per indbygger. Normen bag dette argument er ønsket om etableringen af en basal fordelingsmæssig retfærdighed for at udligne centrets (stor udledning per capita) udnyttelse af periferien (lille udledning per capita) i verdenssystemteorien (Wallerstein 1974). Det er også blevet kaldt princippet om fordeling på baggrund af basale behov (Ringius et al. 2002). Naturen anses i denne skole for at være menneskehedens fælles ejendom, hvorfor ingen kan stilles bedre eller værre end andre i forhold til dens anvendelse. Sker det, er der tale om en form for udnyttelse af dem, som får tildelt færre udledningsrettigheder per capita end andre.

Denne type argumentation ses ofte anvendt af klimapolitiske NGO'ere som kritik af den første og andens skoles dominerende rolle i international klimapolitik. Normen i den tredje skole kommer bl.a. til udtryk i praksis, når det foreslås, at der sker en allokering af udledningsrettighederne til hvert land med udgangspunkt i landets befolkningsstørrelse. Det formuleres under tiden med en analogi fra demokratiske valg som en slags ,one man, one vote"-princip overført til klimapolitikken. Konsekvensen heraf er, at befolkningsrige (men relativt fattige lande) i så fald er berettiget til store dele af verdens drivhusudledninger. Denne argumentationstype er samtidig blevet kritiseret for at ville „belønne“ lande med en uforholdsmæssig stor befolkningstilvækst.

Inden for denne tredje skole i den internationale klimapolitik er der forskellige varianter af forslag til, hvordan man kan ændre udledningsmønstre fra det nuværende til et eventuelt fremtidigt udledningsmønster, hvor alle borgere skal leve op til samme maksimale niveau for udledningen af drivhusgasser. Den radikale version går ind for en ligelig fordeling af udledningerne baseret på den historisk akkumulerede mængde udledninger og ikke kun den nuværende. Tabel 1 viser disse historisk akkumulerede udledninger for de største udledere samt hhv. de industrialiserede lande og udviklingslandene samlet set. Som det fremgår af tabellen, har de industrialiserede lande udledt markant mere end udviklingslandene.

Tabel 1. Landenes andel af de historisk akkumulerede udledninger af drivhusgasser 1840-2005 (i procent)

\begin{tabular}{|l|l|}
\hline Industrialiserede lande $^{8}$ & Ca. 75 \\
\hline Udviklingslande & \\
\hline USA & Ca. 25 \\
\hline Rusland & 27,8 \\
\hline Storbritannien & 8,0 \\
\hline Tyskland & 5,9 \\
\hline Frankrig & 6,7 \\
\hline Japan & 2,7 \\
\hline Kina & 3,6 \\
\hline Indien & 8,1 \\
\hline
\end{tabular}

Kilde: United Nations (2009). Millennium Development Goals Report 2009. 
Den tredje skole repræsenterer således et stærkt egalitært perspektiv med hensyn til international klimapolitik, som naturligt nok kan appellere til klimaaktivistiske kredse. I akademiske kredse har ideen om samme udledningsmulighed per indbygger imidlertid også fået betydelig opmærksomhed i litteraturen (f.eks. Ringius et al. 2002). I den internationale klimapolitik fremføres argumentet tillige blandt visse aktører i udviklingslandene, som ville stå til at få en fordel, hvis skolens anbefalinger blev gennemført. Den tredje skoles normative perspektiv har imidlertid ikke slået rod i nogen form for konkret international beslutning.

\section{Metode}

I det efterfølgende behandles de politiske teoretiske argumenter, som fremføres af hhv. Kina, EU og USA i de internationale klimaforhandlinger vedrørende retten til at udlede drivhusgasser. Der er naturligvis mange forskellige klimapolitiske aktører i disse lande/enheder. Derfor er analysen afgrænset til argumenterne fremført af henholdsvis 1) den kinesiske præsident og premierminister, 2) EU's klimakommissær samt 3) den amerikanske præsident og dennes klimarådgiver.

En sådan afgrænsning udgør naturligvis en begrænsning i forhold til, hvor dækkende analysen er. Den medtager således ikke den brede folkelige og politiske opinion. Afgrænsningen kan imidlertid forsvares med, at netop disse aktører er de mest centrale, når det drejer sig om formuleringen af de internationale klimapolitiske positioner.

Klimapolitikken er et område, som der allerede er publiceret usædvanligt meget om (f.eks. Oberthür og Ott 1999; Giddens 2009; Webster et al. 2012). I denne artikel inddrages kun de dele, som har at gøre med de normative politisk teoretiske begrundelser for fordelingen af udledningsrettigheder. Analysen er endvidere begrænset til at behandle de normative argumenter, som identificeret $\mathrm{i}$ afsnittet om de tre skoler ovenfor. En sådan normativ begrebsanalyse i kombination med det komparative fokus er ikke hidtil blevet gennemført i den klimapolitiske litteratur.

\section{Den normative argumentation i Kinas klimapolitik}

Kina har været sen til at placere klimapolitikken på den politiske dagsorden. Ifølge Kina-forskningen er et vigtigt mål for et emnes betydning i Kinas politiske system dets placering i landets femårsplaner, som fremlægges af den kinesiske præsident. I det følgende antages femårsplanerne at være udtryk for præsidentens og premierministerens position, hvilket naturligvis kun tilnærmelsesvis er sandheden. ${ }^{10}$ Kinas 10 . femårsplan, der blev offentliggjort i 2001, indeholdt den første officielle kinesiske adressering af spørgsmålet om klimaforandringer (Stensdal 2012; i Andersen 2013). Selv om klimaforandringerne kun blev nævnt en enkelt gang i den 10. femårsplan fra 2001, blev det dog bekræftet, at Kina skulle deltage aktivt i globale miljø- og udviklingsspørgsmål (Stendal 2012: 7; i Andersen 2013). Kort efter offentliggørelsen af den 10. femårsplan ratificerede Kina Kyotoprotokollen i 2002 som et ikke-anneks I land uden reduktionsforpligtelser. Det løftede yderligere klimapolitikken op på den politiske dagsorden i Kina.

Perioden frem til 2006 var dog relativt uambitiøs. Årsagen var bl.a., at der stadig var skepsis med hensyn til årsagerne til klimaforandringer. Spørgsmålet om international klimaregulering blev endvidere fra kinesisk side set $\mathrm{i}$ en traditionel Nord-Syd-optik som et udtryk for „miljømæssig imperialisme“ (Yu 2008: 57; i Andersen 2013). Den kinesiske argumentation var således på daværende tidspunkt baseret på normer og argumenter fra den tredje skole angående lighed med hensyn til rettigheder.

Kinas internationale klimapolitik var dermed stadig baseret på, hvad kommentatorer har kaldt "de tre nej'er“: "no obligations on China, no voluntary commitments by China, and no future negotiations to bind China" (Zhang 2003: 67; i Andersen 2013). Kina har således konstant fremhævet landets ret til udvikling (på linje med andre ulande) og har nægtet at acceptere juridisk bindende forpligtelser i de internationale klimaforhandlinger. Argumentationen lød, at det er de industrialiserede lande, som har det historiske ansvar for klimaforandringerne og dermed også ansvaret for at løse den globale klimaudfordring (Bodansky 2010). Samtidig har man også løbende siden 1997 forsvaret sig mod at indgå bindende begrænsninger på baggrund af et bestemt årstal med henvisning til USA's afvisning af at ratificere Kyotoprotokollen. Kina afviser således klart den første skoles normative position om retten til at udlede baseret på et givent historisk basisår. Kinas ledelse ser i det hele taget klimapolitikken i et vækstperspektiv, idet opnåelsen og bevarelsen af høje $ø$ konomiske vækstrater og dermed stigende energiforbrug er altafgørende for, at ledelsen kan bevare legitimiteten i den kinesiske befolkning (Moore 2011; i Andersen 2013).

Fem år senere i 2006 var der i den 11. femårsplan et helt afsnit vedrørende spørgsmålet om, hvordan man imødegår klimaforandringerne. Herunder blev der nævnt såvel ambitiøse kvantitative mål rettet mod at forbedre energiintensiteten, øge skovrejsning og skabe „carbon sinks" for at begrænse udledningerne fra de forskellige forureningskilder. Den 11. femårsplan fra 2006 ændrede således klimapolitikkens status. Præsident Hu Jintao understregede efterfølgende vigtigheden af at tage hånd om klimaforandringerne i sin tale på den 17. partikongres 
for Kinas Kommunistiske Parti i 2007: „We will enhance our capacity to respond to climate change and make new contributions to protecting the global climate" ( $\mathrm{Hu} 2007)$. Dette er imidlertid et udsagn med modifikationer, for Kina ville stadig ikke påtage sig de efterfølgende forpligtende reduktioner i udledningerne på basis af et bestemt år, som der ligger i den første skole.

Kinas nye position fremgår også af National Climate Change Programme fra 2007, hvorefter kontrollen med drivhusgasudledningerne skal ske via videnskabelige fremskridt, ny teknologi og stigende offentlig bevidsthed om spørgsmålet (National Development and Reform Commission 2007: 26; i Andersen 2013). Alt i alt er der således tale om en betydelig forskydning i Kinas klimapolitiske argumentation, hvor Kina påtager sig en rolle i forbindelse med reduktionen af udledningerne. Som nævnt er der dog ikke tale om en argumentation baseret på den første skoles klimapolitiske normer. Forud for COP15 annoncerede den kinesiske premierminister Wen Jiabao i 2009, at Kina ville nedbringe dets udledninger per enhed af bruttonationalproduktet med $40-45$ procent i 2020 i forhold til 2005-niveauet (Jing 2011; i Andersen 2013). Kina har hermed bevæget sig fra normerne i lige rettigheders-skolen (tredje skole) til normerne vedrørende lighed med hensyn til effektivitets-skolen (anden skole).

I 2011 forstærkede og udbyggede den 12. femårsplan de punkter, som nævntes i den 11. femårsplan, men inkluderede også mål vedrørende andelen af ikke-fossil energi i det totale energimiks, investeringer i vedvarende energi og reduktion af kulbaseret energiforbrug i Kina (Andersen 2013: 2). Den 12. femårsplan fra 2011 stadfæstede dermed, at Kina nu klart følger den anden skole med hensyn til normerne for landets klimapolitiske argumentation. En del af femårsplanen består i en yderligere reduktion af energiintensiteten - dvs. den anvendte energi i forhold til det præsterede bruttonationalprodukt - med 16 procent i 2015. Denne reduktion kan synes mindre ambitiøs end de 20 procent, som blev foreslået i den 11. femårsplan. Det kan alligevel vise sig at være sværere at nå de 16 end de 20 procent, fordi de fleste af Kinas lette og hurtige reduktionsmuligheder efterhånden er udnyttet via skrotningen af de „beskidte“ industrier (Lewis 2011; i Andersen 2013). Det er ikke mindst sket via CDM-systemet, jf. ovenfor (Nedergaard 2011).

Herudover satte den 12. femårsplan et foreløbigt mål op vedrørende reduktionen af drivhusgasudledningen per enhed af bruttonationalproduktet på 17 procent i 2015 . Det var også nødvendigt, hvis målet om en reduktion af samme i 2020 på 40-45 procent skulle kunne opnås.

Alt i alt har Kina fastholdt, at man ønsker at reducere udslippene relativt og uden indblanding udefra i modsætning til anneks I-landene under Kyotoprotokollen, som må foretage absolutte reduktioner på baggrund af internationalt bindende aftaler med udgangspunkt i udledningerne i 1990.

Forskellen mellem Kinas relative reduktionsmål og anneks I landenes absolutte reduktionsmål består i, at Kina reducerer udledningerne i forhold til en kontrafaktuel udvikling ${ }^{11}$ og ikke $\mathrm{i}$ forhold til et basisår. Det betyder, at Kina med et relativt reduktionsmål i forhold til bruttonationalproduktet kan udlede en større mængde drivhusgasser, når bruttonationalproduktet vokser. Lande med absolutte reduktionsmål reducerer derimod i forhold til et bestemt basisår. Deres udledninger vil derfor altid være faldende i absolutte tal. Den første skole leverer den normative argumentation, der ligger til grund for Kyotoprotokollen, hvor anneks I lande, der har ratificeret protokollen, skal reducere deres absolutte udledning ift. basisåret 1990. Kina følger derimod på nuværende tidspunkt den anden skole (lighed med hensyn til effektivitet), hvor den politisk teoretiske norm er lighed med hensyn til effektivitet.

Summa summarum: Når det drejer sig om normerne angående Kinas klimapolitiske argumentation vedrørende udledninger af drivhusgasser, har den bevæget sig fra en argumentation baseret på lige rettigheder (tredje skole) til en argumentation fra omkring 2006, som er baseret på normer om lighed med hensyn til effektivitet (anden skole). Kina er stadig langt fra at acceptere normerne bag den første skole, bl.a. fordi det er i landets interesse at undlade at tage dette skridt.

\section{Den normative argumentation i EU's klimapolitik}

I det følgende analyseres EU's normative argumenter vedrørende udledningen af drivhusgasser. Det er klart, at alle EU's medlemsstater ikke har de samme præferencer og derfor heller ikke anvender de samme argumenter i klimapolitikken. I dette afsnit er EU's argumentation derfor analyseret med udgangspunkt i EU-Kommissionen. Afgrænsningen kan forsvares, fordi udledning af drivhusgasser er et EU-anliggende og en del af EU's supranationale kompetence. EU-Kommissionen forhandler på vegne af hele EU i klimaforhandlingerne (Nedergaard 2009).

EU's hovedargumentation i debatten om byrdefordelingen af udledningsreduktioner er, at alle skal bidrage efter „bedste evne“ i forlængelse af princippet om landes falles, men differentierede ansvar (på engelsk common, but differentiated responsibilities og forkortet CBDR), som er forankret i FN's klimakonvention, og som EU har gjort til sit nøgleprincip og grundnorm på det klimapolitiske område. Dette baserer sig på et lighedsprincip, som accepterer, at forskellige grupper af lande kan følge forskellige skoler. 
EU accepterer med andre ord forskellige normer, når det drejer sig om udledninger af drivhusgasser. Argumentet er således, at EU selv (sammen med de øvrige industrialiserede lande) i kraft af dets historie og økonomiske position skal følge lighedsprincippet i den første skole. Det accepteres samtidig, at udviklingslandene af historiske og økonomiske årsager følger den anden skole (Bodansky 2010). På dette punkt adskiller EU's klimapolitiske argumentation sig fra den amerikanske, som fastholder, at alle skal følge samme skole (dvs. den anden skole). Som det vil blive vist nedenfor, minder EU's argumentation derimod om Kinas argumentation i den forstand, at man accepterer forskellige normative skoler for forskellige grupper af lande.

EU's klimakommissær slår således fast, at alle lande skal bidrage med hensyn til at begrænse udledningen af drivhusgasser. Det kan imidlertid dreje sig om både at følge første og anden skole vedrørende normativ klimaargumentation:

„It is important that ALL countries, including emerging economies, contribute to make the world reduce emissions. China's per capita emissions are already higher than the ones of France and Italy. This is an example of how things are rapidly changing" (Hedegaard, 2012a).

EU mener således, at Kina snarest burde følge den første skole (princippet om lighed med hensyn til udledning $\mathrm{i}$ givent basisår), mens Kina kun har villet bevæge sig fra tredje og til anden skole.

EU accepterer, at lande følger forskellige lighedsprincipper, da byrden skal differentieres ud fra nuværende udviklingsniveau. Det betyder, at de mindre udviklede lande også skal bære en del af byrden, men til gengæld får de bedre mulighed for at få en mere udviklet økonomi baseret på grøn teknologi:

„It is clear that different countries with different economies will have to do different things. Some of us reduce our emission already now. Others like for example India will in the first many years strive to do better than business as usual. Nobody would ask more than that. But the point is that all contribute with more efficient use of resources. In Europe we clearly respect the principle of common but differentiated responsibilities" (Hedegaard, 2012a).
EU's normative position på det klimapolitiske område ses også af meddelelsen fra Kommissionen i 2013 om arbejdet for en international klimaaftale i 2015 (Commission 2013). Heri slår Kommissionen fast, at EU godt nok ønsker „environmental effectiveness", men dette skal ske på baggrund af bidrag fra alle store lande og alle sektorer på en "comparable, equitable, transparent and accountable manner that minimises the risk of carbon leak" (Commission 2013).

Kommissionen ønsker med andre ord, at landene udskifter lighedsprincippet i anden skole med lighedsprincippet i første skole, når de bliver rigere og udleder flere drivhusgasser. Det kalder Kommissionen at erstatte den såkaldte "firewall“ mellem industrialiserede (anneks I) lande og udviklings- (ikke-anneks I) lande:

„Europa og USA er enige om, at „firewallen“ mellem industrilande og udviklingslande skal erstattes af et mere differentieret system, som afspejler virkeligheden i det 21. århundrede frem for i det 20. århundrede samt hvert lands ansvar og muligheder. Lad os arbejde sammen om at sikre, at dette sker, og for at nå frem til konsensus om andre aspekter af den globale klimaaftale“ (Hedegaard 2013).

På dette punkt adskiller EU og Kinas normative argumentation sig fra hinanden, idet Kina ikke vil erstatte "firewallen“, da man så risikerer at skulle flytte sig i retning af absolutte udledningsreduktioner på baggrund af et historisk basisår. Kinas tilslutning til Kyotoprotokollen som et ikke-anneks I land er således med til at sikre landet en position som et land, der ikke skal følge første skoles normer. Kyotoprotokollen ser med andre ord på dette punkt ud til at være med til at fastholde „firewallen“ og sikre Kina rollen som potentiel klimapolitisk free-rider. EU ønsker til gengæld et system, hvor man bevæger sig fra den anden til den første skole, når man som land når et vist udviklings- og udledningsniveau. Kommissionen kalder som nævnt dette system at bidrage efter evne:
„EU støtter princippet om fælles, men differentieret ansvar og respektive kapacite- ter. Men det må aldrig være en undskyldning for ikke at gøre noget. Klimaudfordringen kan kun tackles, hvis alle bidrager efter bedste evne. Her i det 21. århundrede er vi alle afhængige hinanden, og vi skal alle bidrage til de fælles udfordringer" (Hedegaard, 2012b).

Alt $\mathrm{i}$ alt introducerer EU således en glidende overgang i normgrundlaget med hensyn til den klimapolitiske argu- 
mentation, idet lighed opfattes forskelligt alt efter, hvilket økonomisk udviklingstrin landene befinder sig på. Målet er imidlertid, at alle lande skal bevæge sig i retning af første skole, og det accepteres, at EU befinder sig her, samt at USA burde tilslutte sig denne skole. Kina burde ifølge EU også være på vej fra den anden og til den første skole.

\section{Den normative argumentation i USA's klimapolitik}

Et af de områder, hvor EU og USA er uenige, drejer sig om udviklingslandene, hvor EU accepterer, at der anvendes forskellige politisk teoretiske lighedsbegreber i forbindelse med udledningsbegrænsningerne, mens USA ikke accepterer en sådan forskellighed. Der er som sådan ikke noget nyt forbundet med USA's ønske om at inkludere udviklingslande som forpligtede parter i et klimapolitisk regime. Det ønskede man allerede i forbindelse med forhandlingerne om Kyotoprotokollen, hvor USA skubbede på for at få udviklingslandene inddraget (Bodansky 2010: 232). Selv om EU og USA således har været og stadig er uenige på en række punkter i klimapolitikken, så går den centrale kløft mellem de industrialiserede lande og udviklingslande, idet sidstnævnte langt hen ad vejen stadig opfatter sig som tilhørende den tredje normative skole (Kina undtaget) (Bodansky 2010: 232) begrundet i deres historisk lave udledninger, jf. tabel 1 ovenfor.

I den eksisterende litteratur er der imidlertid en tendens til at fokusere på forskellene mellem EU og USA, da de historisk har været de ledende spillere på området. Det har ført til en del undersøgelser af forskellene mellem USA og EU, selv om den største forskel i klimapolitikken snarere skal findes i skillelinjen mellem industrialiserede lande og udviklingslande (Szarka 2012).

Først og fremmest er det vigtigt at bemærke, at USA er relativt polariseret indenrigspolitisk, når det kommer til klimapolitik med de langt mere klimaskeptiske republikanere på den ene side og de mere klimaambitiøse demokrater på den anden side (McCright og Dunlap 2008).

Hvis man ser på præsident Obamas normative argumentation i klimaspørgsmålet, gælder det stadig, at USA langt fra fuldt ud accepterer CBDR-princippet. Mange har f.eks. peget på præsident Obamas FN-tale fra 2009, hvori han siger, at:

„We also cannot allow the old divisions that have characterized the climate debate for so many years to block our progress. Yes, the developed nations that caused much of the damage to our climate over the last century still have a responsibility to lead. ... But those rapidly-growing developing nations that will produce nearly all the growth in global carbon emissions in the decades ahead must do their part as well. ... We cannot meet this challenge unless all the largest emitters of greenhouse gas pollution act together" (Obama 2009).

Heri lyder Obama som én, der synes, at alle udledende lande skal samarbejde på lige fod om at bidrage med store reduktioner, hvilket kan synes at stride mod CBDRprincippet. USA ønsker tilsyneladende også under en demokratisk præsident, at alle lande skal opfattes som hørende til samme skole, selv om USA's klimaforhandler og klimapolitisk rådgiver for præsidenten, Todd Stern, har nævnt, at USA er villig til i det mindste at diskutere CBDR-princippet (The Sydney Morning Herald, 6. december 2012).

USA har foreslået et format til afløsning af Kyotoprotokollen, der baserer sig på nationale udmeldinger af reduktioner og efterfølgende brug af „peer pressure“ (McCright og Dunlap 2008). Samtidig har USA også ofte bevidst skubbet på for at få fjernet CBDR-princippet fra den klimapolitiske dagsorden (The Sydney Morning Herald, 6. december 2012). I spørgsmålet om karakteren af forpligtelser ligger USA mere på linje med Kina end med EU, da USA heller ikke er videre villig til at acceptere de forpligtende reduktioner.

Ifølge Todd Stern, er der behov for realistiske ambitioner:
„Anyone can say we're going to demand strict legally binding commitments to slash our emissions and to have those commit- ments subject to a rigorous compliance regime with tough penalties for non-compli- ance, and by doing this fix the climate problem once and for all. The trouble is that this kind of approach won't work because too many countries would see it as threate- ning to their core interests in growth and development. This is paper ambition, but we need real ambition“ (Stern 2013).

USA opfatter med andre ord første skole som urealiserbar, og man er heller ikke tilhænger af EU's dobbelte normgrundlag, som også ligger til grund for CBDR-princippet (The Sydney Morning Herald, 6. december 2012). Alt i alt er det politisk teoretiske grundlag for USA's klimapolitiske argumentation vedrørende udledninger af drivhusgasser således lighed med hensyn til effektivitet (anden skole). USA kunne acceptere den første skole, hvis alle lande var med, men man finder EU's dobbelte normposition uacceptabel. 
Derfor befinder USA's klimapolitiske argumentation sig et sted midt imellem EU og Kina. Det ses også bekræftet i praksis af, at USA for nylig har indgået et tæt samarbejde med Kina med henblik på de kommende internationale klimaforhandlinger (Joint US-China Statement on Climate Change 2013), som for nylig blev bekræftet på mødet mellem den amerikanske og kinesiske præsident.

\section{Konklusioner}

Antagelsen bag artiklen er, at der bag de vigtigste aktørers positioner i den internationale klimapolitik gemmer sig nogle væsensforskellige opfattelser og normer for, hvordan fordelingen af CO2-reduktioner skal være. Disse normer er langt fra konsistente og varierer alt efter, hvilke aktører reduktionskravene er rettet imod. De forskellige normative udgangspunkter har betydning for aktørernes positioner i de internationale klimaforhandlinger og dermed den vigtige diskussion om byrdefordelingen af reduktionsforpligtelser $\mathrm{i}$ en eventuel fremtidig klimaaftale i 2015 .

I denne artikel er verdens klimapolitiske hovedaktører - afgrænset til Kina, EU og USA - analyseret med et komparativt sigte på basis af, hvilke politisk teoretiske normer om lighed, aktørerne anvender som grundlag for deres argumentation for fordelingen af udledningsreduktionerne i den internationale klimadebat. Det er sket på baggrund af en opdeling af normer om lighed i tre skoler.

Det påvises i artiklen, at Kina i løbet af de seneste ti år har skiftet fra én normativ politisk skole til en anden. EU viser sig at have ét sæt af normative begrundelser for de industrialiserede landes udledningsreduktioner og ét andet sæt for udviklingslandene, hvor Kina betragtes som værende på vej mod den første gruppe. Endelig svarer USA's normative politisk teoretiske begrundelser for allokeringen af udledningsreduktionerne overvejende til Kinas nye normative position, idet man opfatter EU's normative begrundelser som urealistiske.

Påvisningen af de bagvedliggende forskelligartede og langt fra konsistente normer om lighed kan forhåbentlig give en dybere forståelse af, hvorfor de analyserede hovedaktører agerer, som de gør i den internationale klimapolitik. En del af forklaringen, på hvorfor de internationale klimaforhandlinger har så svært ved at komme ud af stedet, er muligvis, at hovedaktørerne ikke tilstrækkeligt nuanceret forstår hinandens normative positioner. I tabellen neden for fremgår resultaterne af analysen i sammenkogt form. Disse resultater er ikke tidligere påvist.

Tabel 2. Sammenligning af lighedsprincipper vedrørende udledning af drivhusgasser i Kina, EU og USA

\begin{tabular}{|c|c|c|c|}
\hline Lighedsprincipper & Kina & EU & USA \\
\hline $\begin{array}{l}\text { Første skole } \\
\text { („Equal Burdens“) }\end{array}$ & $\begin{array}{l}\text { Kinas position for velstående, indu- } \\
\text { strialiserede lande med en historisk } \\
\text { set stor udledning. }\end{array}$ & $\begin{array}{l}\text { EU's position for de velstående, } \\
\text { industrialiserede lande og herunder } \\
\text { EU selv. }\end{array}$ & $\begin{array}{l}\text { Ifølge USA den ideelle, men urealisti- } \\
\text { ske position for alle lande. }\end{array}$ \\
\hline $\begin{array}{l}\text { Anden skole } \\
\text { („Equal Efficiency“) }\end{array}$ & $\begin{array}{l}\text { Kinas nuværende position for landet } \\
\text { selv og for udviklingslandene som } \\
\text { helhed (sidstnævnte er ikke fremgået } \\
\text { af analysen). }\end{array}$ & $\begin{array}{l}\text { EU's position for udviklingslandene, } \\
\text { idet EU's position er differentieret alt } \\
\text { efter landetype. }\end{array}$ & $\begin{array}{l}\text { USA's position for alle lande, herunder } \\
\text { USA selv. }\end{array}$ \\
\hline $\begin{array}{l}\text { Tredje skole } \\
\text { („Equal Rights") }\end{array}$ & $\begin{array}{l}\text { Kinas tidligere position for landet selv } \\
\text { og udviklingslandene som helhed. }\end{array}$ & & \\
\hline
\end{tabular}




\section{Referencer}

Andersen, K.S. (2013). China's Climate Policy. An Interest-Based Explanation. Kandidatafhandling ved Institut for Statskundskab, Københavns Universitet.

Bodansky, D. (2010). The Copenhagen Climate Change Conference: A Postmortem, The American Journal of International Law, vol. 104 (2), pp. 230-240.

Commission (2013). The 2015 International Climate Change Agreement: Shaping international climate policy beyond 2020. Bruxelles.

Financial Times (2013). „UK climate scientists say oceans hold key as global warming slows" By Pilita Clark Lokaliseret den 10 september 2013: http://www.ft.com/cms/ s/7a8529ec-f2d1-11e2-a203-00144feabdc0, Authorised=false. htm l?_i_location =ht t p \% 3 A 2 F \% $2 \mathrm{Fwww}$. ft.com\%2Fcms $\% 2$ Fs $\% 2$ F0\%2F7a 8529 ec-f2d1-11e2-a 203 00144feabdc0.html\%3Fsiteedition\%3Duk\&siteedition=uk\&_i referer=\#axzz2eTC5bzNc

Giddens, A. (2009). The politics of climate change. Cambridge, UK.

Hedegaard, C. (2012a). Getting more for less. 12th Delhi Sustainable Development Summit, 3. februar 2012. Lokaliseret den 28. maj 2013: http://ec.europa.eu/commission_2010-2014/hedegaard/ headlines/news/2012-02-03_01_en.htm

Hedegaard, C. (2012b). Klimaændringer. Vores fælles ansvar. Vores fælles udfordring. Connie Hedegaards tale ved AMCEN-ministermøde i Arusha (Tanzania), 14. september 2012. Lokaliseret den 28. maj 2013: http://ec.europa.eu/commission_2010-2014/hedegaard/ headlines/news/2012-09-17_01_da.htm

Hedegaard, C. (2013). Kampen mod klimaforandringerne i en krisetid. Connie Hedegaards tale på Konference om Europa, Harvard Universitet, 3. marts 2013. Lokaliseret den 28. maj 2013: http://ec.europa.eu/commission_2010-2014/hedegaard/headlines/ news/2013-03-03_01_da.htm

Hu Jintao (2007). Full text of Hu Jintao's report at 17th Party Congress. Lokaliseret den 1. oktober 2012: http://news.xinhuanet.com/ english/2007-10/24/content_6938749.htm

Hume, D. (2004) [1739]. A Treatise of Human Nature. New York: Dover Publications.

Jing, Li (2011). Carbon intensity targets unveiled. China Daily, March 1, 2011. Lokaliseret den 5. September 2012: http://www.chinadaily. com.cn/china/2011-03/01/content_12092285.htm

Joint US-China Statement on Climate Change (2013). 13. April 2013. Lokaliseret den 28. maj 2013: http://www.state.gov/r/pa/prs/ ps/2013/04/207465.htm

Lewis, J.I. (2011). Energy and Climate Goals of China's $12^{\text {th }}$ Five-Year Plan. Pew Center. Lokaliseret den 4. oktober 2012: http://www. c2es.org/docUploads/energy-climate-goals-china-twelfh-five-yearplan.pdf

Locke, J. (1980) [1690]. Second Treatise of Government. Cambridge, MA: Hackett Publishing.

McCright, A.M. og R. E. Dunlap (2008). The Politization of Climate Change and Polarization in the American Public's views of global Warming, 2001-2010. The Sociological Quarterly 52 (2011), pp. 155-194.

Moore, S. (2011). Strategic Imperative? Reading China's climate policy in terms of core interests. Global Chaange, Peace \& Security, 23(2), pp. 147-157.

National Development and Reform Commission (2007). China's National Climate Change Programme. Lokaliseret den 18. September 2012: http://www.ccchina.gov.cn/WebSite/CCChina/UpFile/ File188.pdf
Nedergaard, P. (2011). „The Political Economy of the Clean Development Mechanism (CDM) Governance System“. Working paper. Department of Political Science, Copenhagen.

Nedergaard, P. (2009). „Hvem skal lede verdens klimapolitik?“, I: Peter Nedergaard og Peter Fristrup (red.) (2009). Klimapolitik - dansk, europæisk, globalt. Jurist- og Økonomforbundets Forlag, pp. 135 156.

Nielsen, H., H. Siggaard Jensen og K. Nielsen (2005). Skruen uden ende - den vestlige teknologis historie. Nyt Teknisk Forlag.

Obama, B. (2009). Speech at United Nations General Assembly, 22. september 2009, New York Times, Lokaliseret den 28. maj 2013: http://www.nytimes.com/2009/09/23/us/politics/23obama.text. html?pagewanted=all\&_r $=0$

Oberthür, S. og H.E. Ott (1999). The Kyoto Protocol. International Climate Policy for the 21st Century. Berlin: Springer.

Polo, I., Dong, B. W. and Sutton, R. T. (2013). Changes in tropical Atlantic interannual variability from a substantial weakening of the meridional overturning circulation. Climate Dynamics.

Raymond, L. (2008). Allocating the Global Commons: Theory and Practise. I: S. VanderHeiden og J. Barry (red.), Political Theory and Global Climate Change. Cambridge: The MIT Press.

Ringius, L., P. Frederiksen og K. Birr-Pedersen (2002). Burden Sharing in the Context of Global Climate Change. A North-South Perspective. National Environment Research Institute, Report No. 424.

Stensdal, I. (2012). China's Climate-Change Policy 1988-2011: From Zero to Hero? Fridtjof Nansen Institute. Lokaliseret den 10. september 2012: http://www.fni.no/doc\&pdf/FNI-R0912.pdf

Stern, T. (2013). Remarks at Secretary Clinton's Foreign Affairs Policy Board Meeting, 5. januar 2013. Lokaliseret den 28. maj 2013: http://iipdigital.usembassy.gov/st/english/texttrans/2013/01/20130105140665.html\#axzz2HWLDa2e1

Szarka, J. (2012). The EU, the USA and the climate divide: reappraising strategic choices, European Political Science, 11, pp. 31-40.

The Sydney Morning Herald (2012). „Big shifts“ seen in US position at Doha climate talks. 6. december 2012. Lokaliseret den 2. September 2013.

Wallerstein, I. (1974). The Modern World-System, vol. I: Capitalist Agriculture and the Origins of the European World-Economy in the Sixteenth Century. New York/London: Academic Press.

Webster, M., Sokolov, A. P., Reilly, J. M., Forest, C. E., Paltsev, S., Schlosser, A., ... \& Jacoby, H. D. (2012). Analysis of climate policy targets under uncertainty. Climatic change, 112(3-4), 569-583.

Yu, Hongyuan (2008). Global Warming and China's Environmental Diplomacy. Nova Science Publishers: New York.

Zhang, Zhihong (2003). The forces behind China's climate change policy: interests, sovereignty, and prestige. I.: P.G. Harrins (red.) Global Warming and East Asia: The domestic and international politics of climate change. Routledge: New York.

\section{Noter}

1. Morten Holm-Hemmingsen har været forskningsassistent på denne artikel. Jeg har også fået gode kommentarer fra en anonym bedømmer og fra POLITIKs redaktion.

2. Akronym for "United Nations Framework Convention on Climate Change".

3. Humes princip om ejendomsretten fremlægges i afsnittet "Of the Rules Which Determine Property".

4. Lockes princip om ejendomsretten stammer fra kapitel V "Of Property".

5. Kyotoprotokollen til UNFCCC blev indgået i Kyoto i Japan. Protokollen indebærer, at udslip af drivhusgasser fra anneks I landene skal 
reduceres med 5,2 procent i forhold til 1990-niveau gennemsnitligt i selve perioden 2008-2012. Protokollen indebærer bl.a., at EU skal reducere sine udslip med 8 procent og USA med 7 procent, hvilket f.eks. på grund af den forskelligartede befolkningsvækst stillede USA i en ringere situation end EU. Kina stod derimod ikke overfor nogen form for reduktionskrav. USA trådte ud af Kyotoprotokollen i 2001. Kyotoprotokollen er blevet forlænget i en anden forpligtelsesperiode fra 2013-2020.

6. Anneks I lande er de industrialiserede lande, der er oplistet i et bilag til Kyotoprotokollen, og som får en regulering af deres fremtidige udledning af klimagasser, hvis de ratificerer aftalen. Hertil hører EU og USA.
7. Ikke-anneks I lande er alle andre lande, dvs. udviklingslandene. Disse lande skal ikke foretage begrænsninger i deres udledninger i kraft af aftalen, selv om de ratificerer den. Kina tilhører denne gruppe af lande. Kyotoprotokollen er ratificeret af EU og Kina, men ikke af USA.

8. Anneks I lande

9. Ikke-anneks I lande

10. Fra og med den 11. femårsplan er "plan“ (kinesisk: jibuä) officielt udskiftet med begrebet „guideline“ (kinesisk: guìhuà ). I det følgende anvendes imidlertid konsekvent begrebet "plan“.

11. Det vil sige i forhold til, hvad Kina ville have udledt i fraværet af $\mathrm{CO} 2$-reducerende tiltag. 